\title{
Use of Mangrove Swamps for Agricultural and House Construction Activities: A Study of Devgad and Rajapur Tehsils of Coastal Maharashtra
}

\author{
Nisha R. Mugade and Jagdish B. Sapkale* \\ Department of Geography, Shivaji University, Kolhapur - 416004, Maharashtra, India; nish8187@gmail.com; \\ sapkalejagdish@gmail.com
}

\begin{abstract}
Background/Objectives: The attempted research is the outcome of the questionnaire based analysis about the use of mangrove swamps for agricultural and house construction activities. The present research study also assesses the impact of such human activities on the degradation of mangroves. Methods/Analysis: Present research work consists of primary data, collected through field survey and through the questionnaires in 23 villages of the Devgad and Rajapur Tehsils of Coastal Maharashtra. Questionnaire is formulated on account of all the relevant aspects in terms of interaction between man and mangroves, use of mangroves for construction activities, tourism development in mangrove area, waste water disposal in estuary, agriculture practice in mangrove fields etc. For the collection of large data/ information, stratified random sampling method was used. Findings: Along the estuaries of the study area the land is quite fertile for agricultural purposes. During the questionnaire survey, it has observed that the villagers, who are living near the mangrove areas are encroaching their agricultural fields towards the mangroves. Applications/Improvements: In view of government rules and regulations for the protection of the mangroves, it requires collecting and assessing the basic information and database about the mangroves. Such collected basic information also helps for the proper management of mangrove ecosystem.
\end{abstract}

Keywords: Agricultural Activities, Conservation of Mangroves, Mangroves, Perception of Villagers, Questionnaire Survey

\section{Introduction}

Today, disastrous incidents are taking place due to natural catastrophes. Coastal tracts of any country are more prone to tsunami and cyclonic disasters. Mangroves are the natural protective defensive natural resource that protects the coastal areas from natural hazards. Differentiate human activities are directly or indirectly influencing mangroves. The coast is a zone with a differentiate landscapes which are formed by the active erosional and depositional processes of sea action. The existing part between land and sea are the coastal land forms i.e. cliff, rocky, platform beaches, sand bars, sand spits etc. The mangrove is the associated part of the coastal tracts which also protects the coastal land forms and coastal environment $\frac{1,2}{2}$.
Along the coastline of Devgad and Rajapur Tehsils of Maharashtra (Figure 1), there are mud flats or swamps, covered by Mangroves. Mangroves are well developed in the inter-tidal zones of estuaries. Estuaries lies in the Devgad and Rajapur are very rich in Mangrove resource. Most of the mangrove resources are degraded due to the human interventions only. Observed degradation of mangrove in the study area is the result of mangrove utilization for various purposes like construction (building material), agriculture, fishing, fuel wood, Disposal of waste water etc. Diversified social groups living in different locations have their own views to understand surrounding ecosystem or environment. Conservation as well as degradation of ecosystem is highly influenced by their perceptions. Natural resources which are avail-

${ }^{*}$ Author for correspondence 
able in the surrounding environment are used frequently by the human beings. Mangrove resource is one of them. There are different exploitation patterns of mangroves by the population of coastal area. Wooden material for construction purpose, agriculture in mangrove area, tourism development, and waste water disposal are the activities which influenced on the mangrove ecosystem in Devgad and Rajapur tehsils.

\section{LOCATION MAP OF THE STUDY AREA}

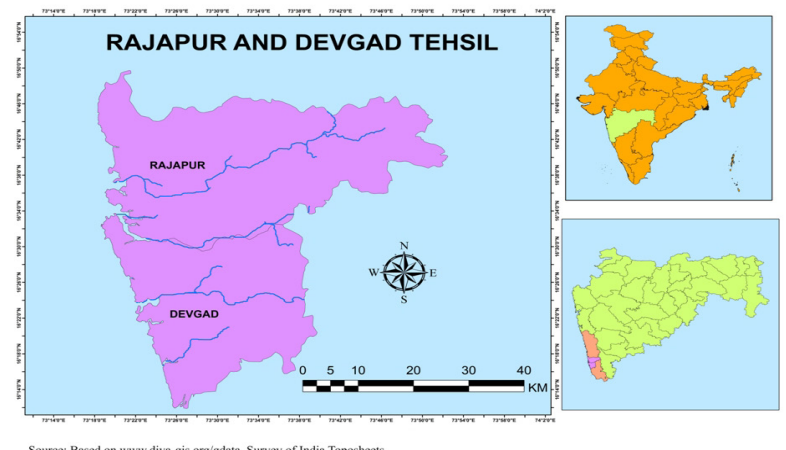

Figure 1. Location map.

Mangrove is a dynamic ecosystem, which provide differentiate habitat pattern, metals, nutrients, food product for a large number of residents and a variety of animals and organisms. Apart from this, also provide defensive systems for coastal settlements and coastal landforms ${ }^{3}$. The tidal and wave energy is also contributing for the formation of coastal landscapes and also influencing on mangrove soil and mangrove areas $\frac{4,5}{.}$. The baseline survey of coastal area is also important to assess the impact of human activities on coastal landscapes, such study is useful for understanding the coastal processes and coastal morphology $y^{\underline{6}}$. According to ${ }^{\underline{7}}$ species of the mangrove are used for the increasing production of fish within the estuary and branches of mangroves used for honey collection. Mangrove stems are used for building purpose and are varies with the type of the building. The average diameter of mangroves poles that is used for construction of houses also indicates the variation in size i.e. wall poles have approximately with a diameter of 6-7 $\mathrm{cm}$ and for the roof poles the diameter is $5-6 \mathrm{~cm}$, such poles made up of mangroves can be used for fencing purpose $e^{7}$. These all exploitation pattern of mangrove more or less influencing on the extent of mangrove swamps.

Besides this the another reason for the mangrove destruction in India is aquaculture and agriculture expansion, use of mangrove for timber, fuel and charcoal, pollution, natural calamities, climate change and reduction of fresh water and uneven distribution of tidal water flows ${ }^{\underline{8}}$. Tin-mining activities and intensive shrimp farming activities are also causes behind degradation of mangroves forest, loss of mangrove and ecological disturbance?

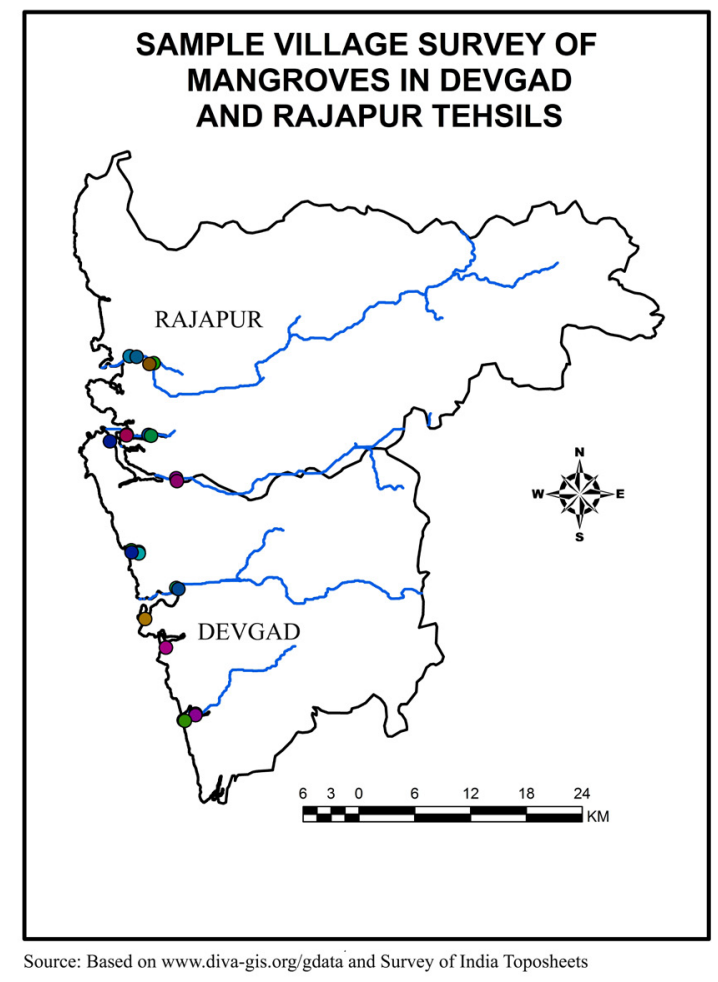

Figure 2. Village Locations on map.

To monitor the area of mangrove under threat, now a day's GIS Remote sensing techniques becomes a powerful tool. GIS can help to collect data about the silvi-culture, forest cover, settlements etc. and this readily available data helps to identify how much forest cover present and how much degraded where and when. It is also helps to identified different species. It is a significant system that will helpful in sustainable management of mangrove $e^{10}$.

According to ${ }^{11}$ in Kenya also, mangrove degradation is observed mainly due to the Mangrove harvesting for the consumption of fuel wood, exported as building material and fire wood to the Somalia, Saudi Arabia and other Middle East Countries. Some of the mangroves were used for making furniture, cooking utensils, fishing traps and sailboat and building houses. Villager's lifestyle depends upon the mangrove ecosystem because fisherman are 


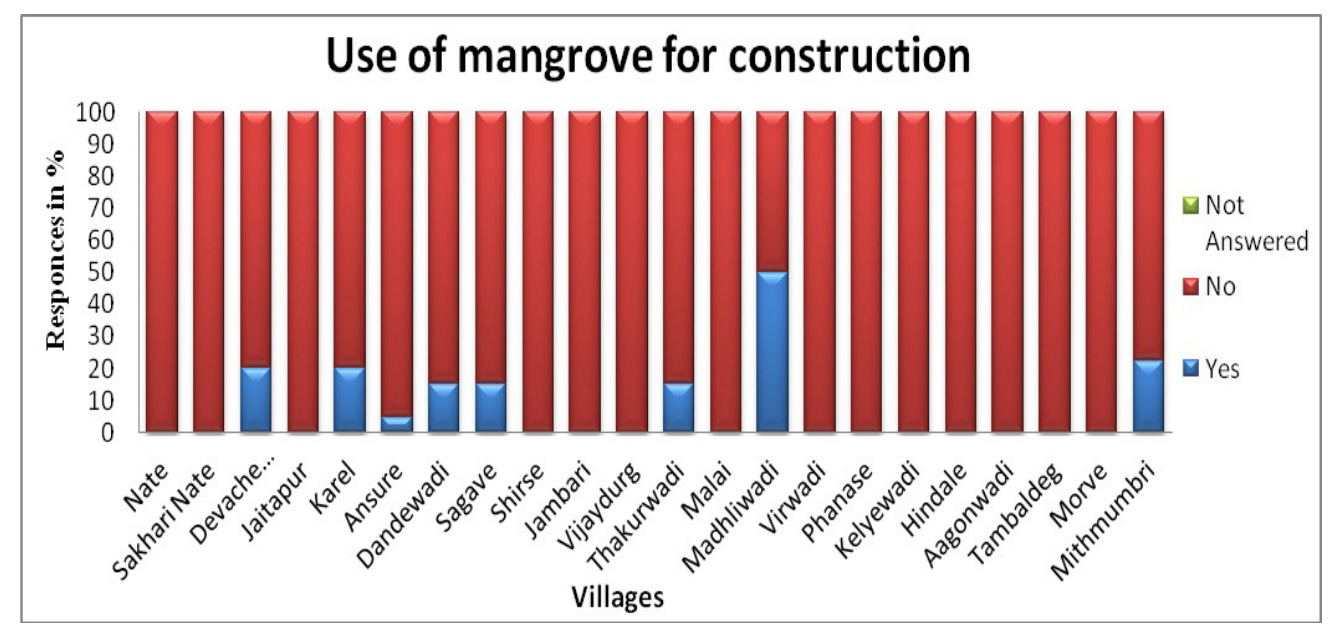

Figure 3. Use of mangrove for construction.

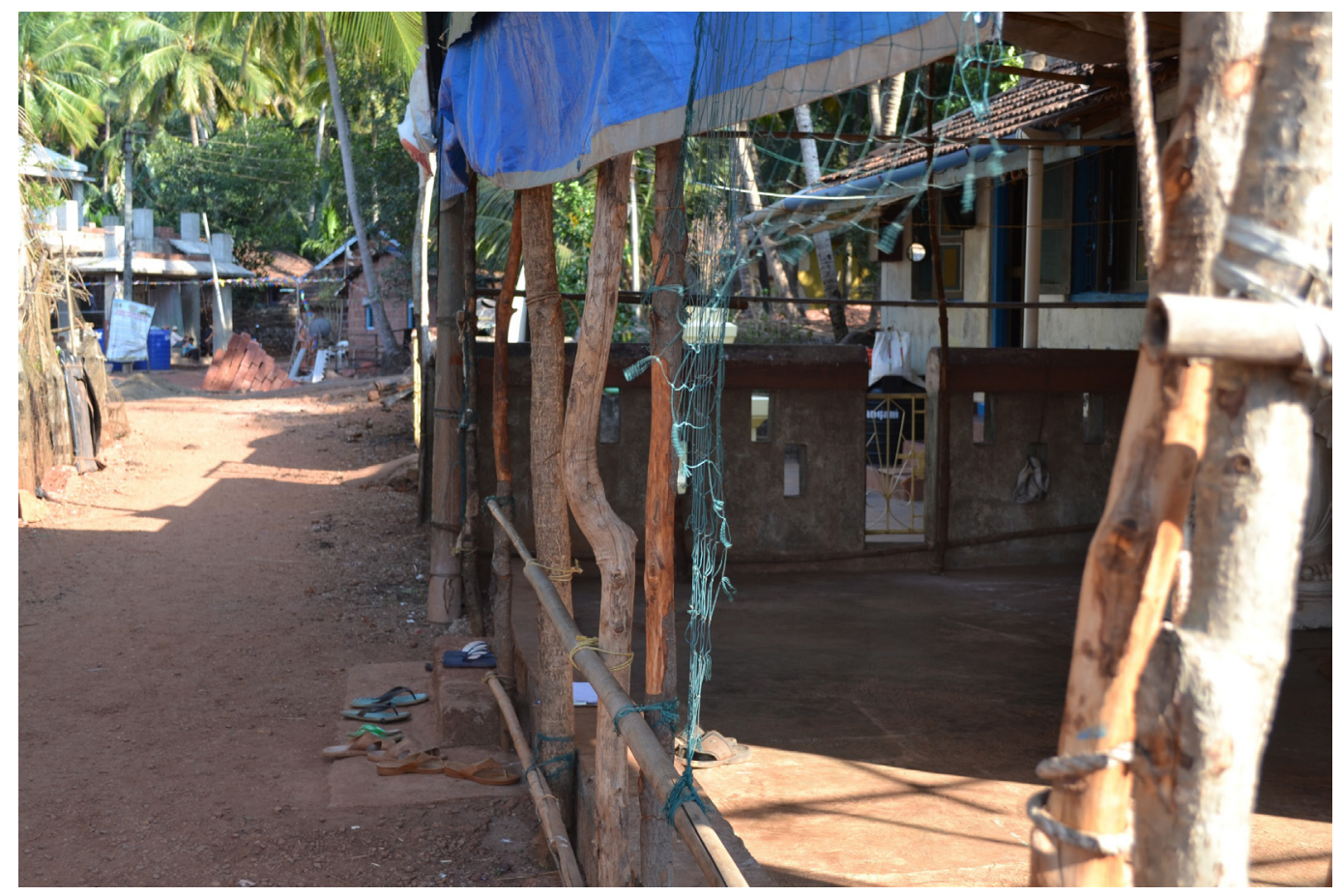

Figure 4. Mangroves used for construction in Madhliwadi village.

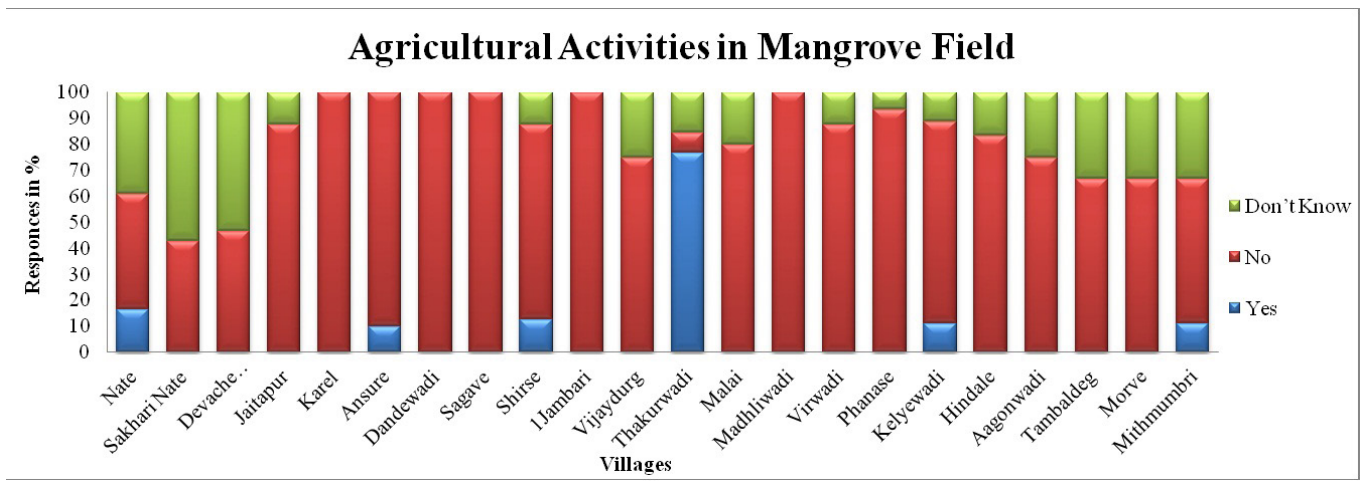

Figure 5. Agricultural activities in mangrove field. 


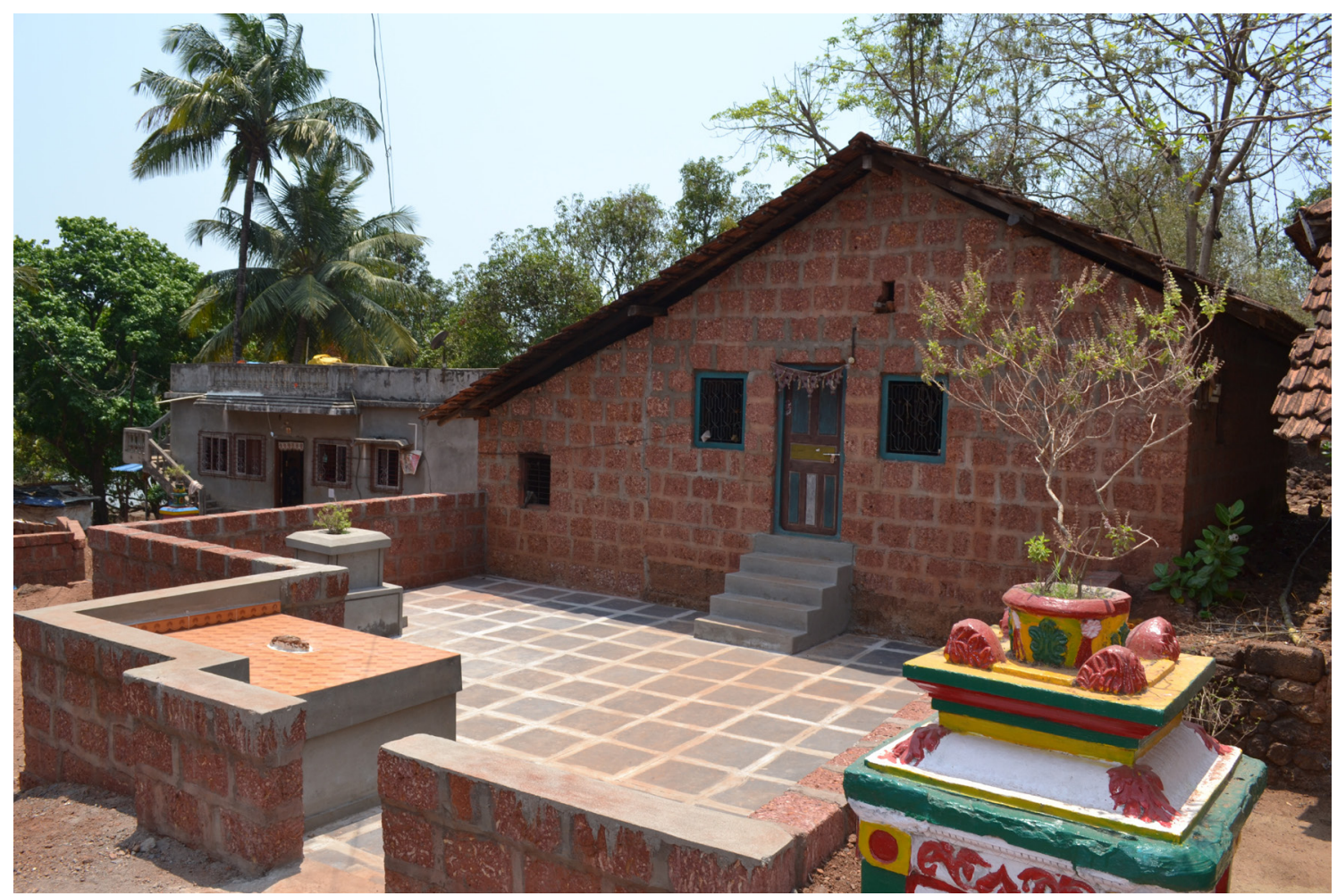

Figure 6. Houses in study area.

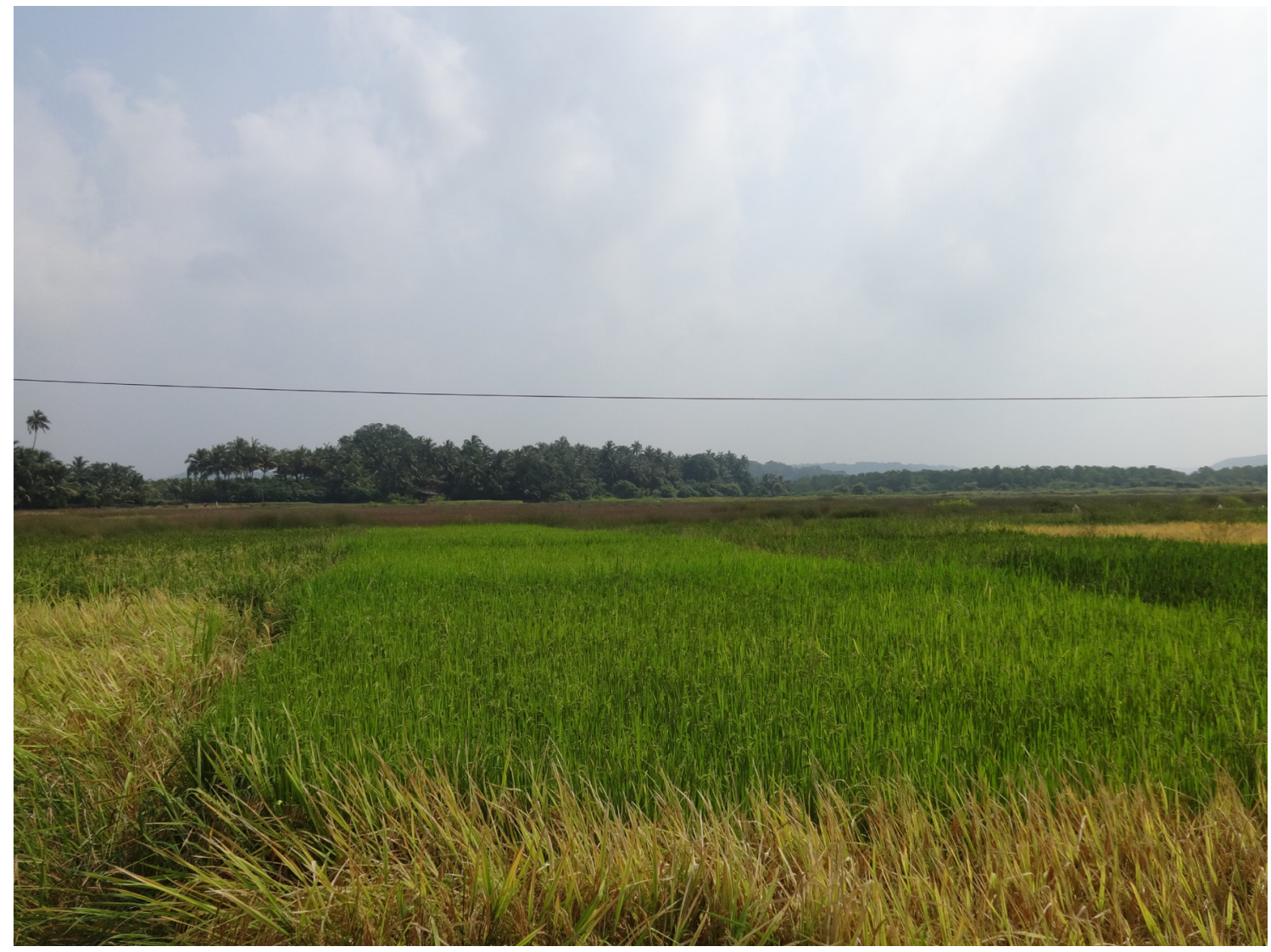

Figure 7. Rice fields along Rajapur the estuary. 
also depends on fish and shrimps, which is found in mangrove ecosystems $\mathrm{s}^{11}$. In the study area it has seen that some estuarine beds have been excavated for the use of sea sand, which also distributing the adjacent mangrove swamps. Generally the material composite of silt and clay varies from place to place. The sea sand is inferior to the river sand and not as important for making concrete in coastal construction activities $\frac{12,13}{}$. The silt, sand and clay material is deposited on the surface soil of the mangrove swamps and the accumulated material also resulting for the uneven growth of mangroves. So according to ${ }^{14}$ the assessment of suspended sediment concentration in surface water can be quantify using MODIS and $\mathrm{ANN}^{14}$. In the study area of ${ }^{15}$ Yifeng Estuary of Shantou City, south eastern China, the authors concluded that re-growth or re-plantation of mangroves are alternately influenced on the content and deposition of organic material and heavy metals. That means the mangrove forest also acts for the oxidation processes, which supports the habitat of micro organisms $\frac{15}{}$.

Mangroves ecosystem developed in inter tidal zones of the estuaries. They required shallow tidal water and fine sediment to grow. Mangroves are important natural resource in the coastal area which protects inland ecosystem as well as coastline. Mangroves protect coastline from cyclones, flash floods, tsunamis and surges. Mangroves reduce the velocity of wind and wave. Mangroves in the estuary are rich in biodiversity so, they providing shelter for the various aquatic microorganism and animals. But various practices by the local people cause degradation of mangroves. Mangroves are continuously under the threat by the local population.

\section{Methods}

Primary data is collected through field survey and through the questionnaires in 23 villages of the study area (Figure 2). Collected data was converted into percentage. Questionnaire is formulated on account of all the relevant aspects in terms of interaction between man and mangroves, questionnaire consist information about mangroves like use of mangroves for construction, tourism development in mangrove area, waste water disposal in estuary, agriculture practice in mangrove fields etc. The methodology also includes: individual household case study. Door to door house hold survey was carried out. For the collection of large data/ information, stratified random sampling method was used. For that questionnaires were filled from the villages situated along the right and left banks of mouth and middle zones of estuary. Upper zone was avoided because of absence of mangroves there.

\section{Discussion}

The Rajapur and Devgad tehsils of Maharashtra coasts are having undulating landscapes. The agricultural lands are very less as compare to inland Tehsils of Maharashtra. The estuaries like Rajapur, Karivane, Vijaydurg, Phanase, Devgad, Mithbav and Mithmumbri are the part of these two tehsils. Along the estuaries the land is quite fertile for agricultural purposes. The agricultural farmlands are very small in patches and having some moderate to high moderate slopes. Along the estuaries, at an elevation of 3 to 4 metre from its mean sea level the land is swampy and mostly favourable for the growth of mangroves. In view of the coastal resource management and the protection act, most of the coastal population are trying to protect the mangrove unwillingly. Some people are afraid of government rules and regulation regarding the mangroves. They are most probably hiding the information about the mangrove degradation. During the questionnaire survey, it has observed that the villagers, who are living near the mangroves areas are encroaching their agricultural fields towards the mangroves. The authors were attempting to collect the primary data about the agricultural activities and other activities and their effects on the mangroves. The perception based information of the villagers about the mangroves are as follows:-

On the basis of questionnaire survey the perceptions and opinions of local residents about the use of mangroves for construction purpose have displayed by graphs. Figure 3 shows the Village-wise perception about use of mangrove wood for construction purpose. About $15.4 \%$ respondents in Dandewadi, Thakurwadi Sagave used mangroves for construction purpose respectively; and 5\% in Ansure; 20\% in Karel, Devache, Ghotane and Mithmumbri respectively; and about 50\% respondents in Madhaliwadi are used mangroves for the same activities. They used mangroves for building houses or shelters, because the wood of mangroves is very cheap and easily available in their region (Figure 4). They used healthy mangroves for construction purpose. This is very cheap but the same is decaying in fresh water that's why not that 


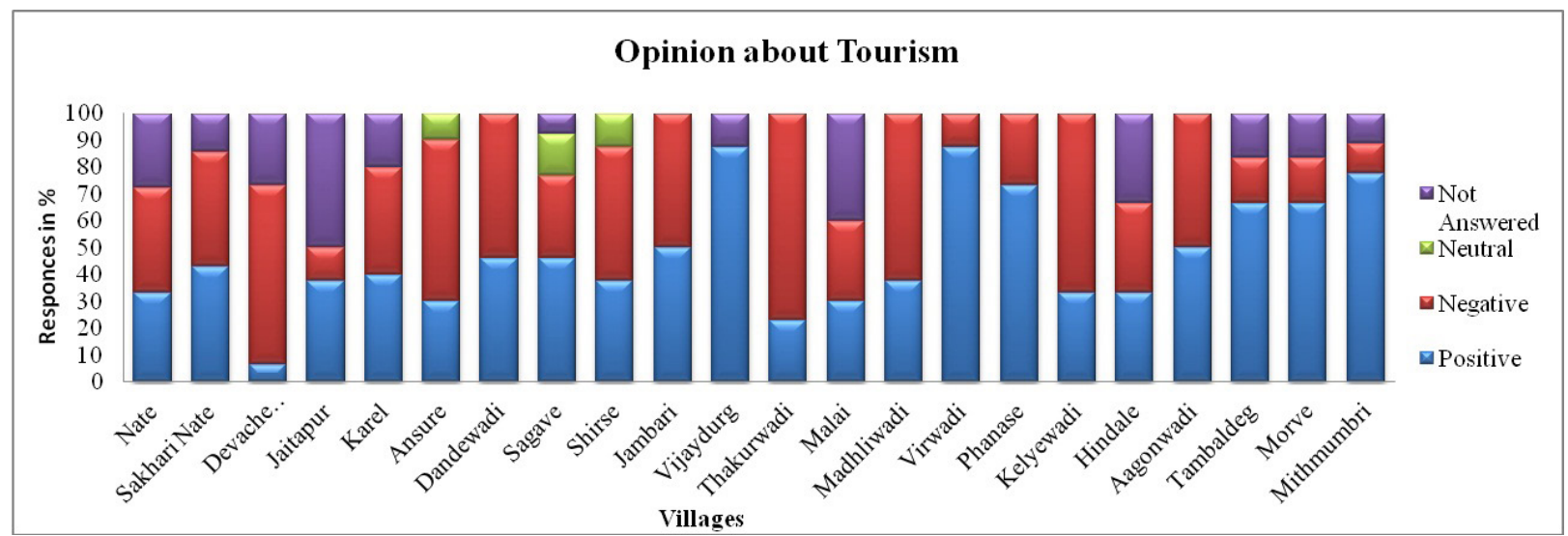

Figure 8. Opinion about tourism.

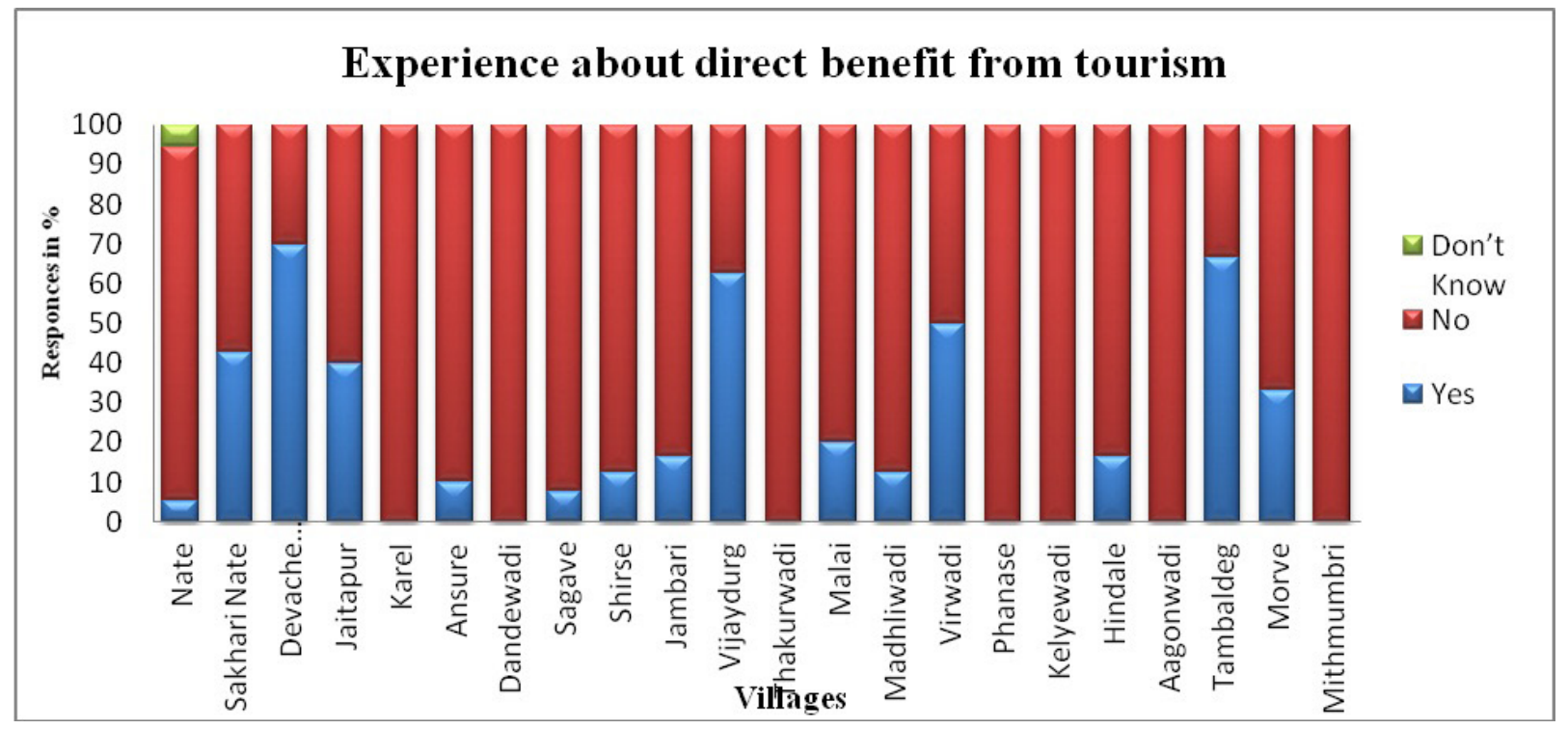

Figure 9. Experience about direct benefit from tourism.

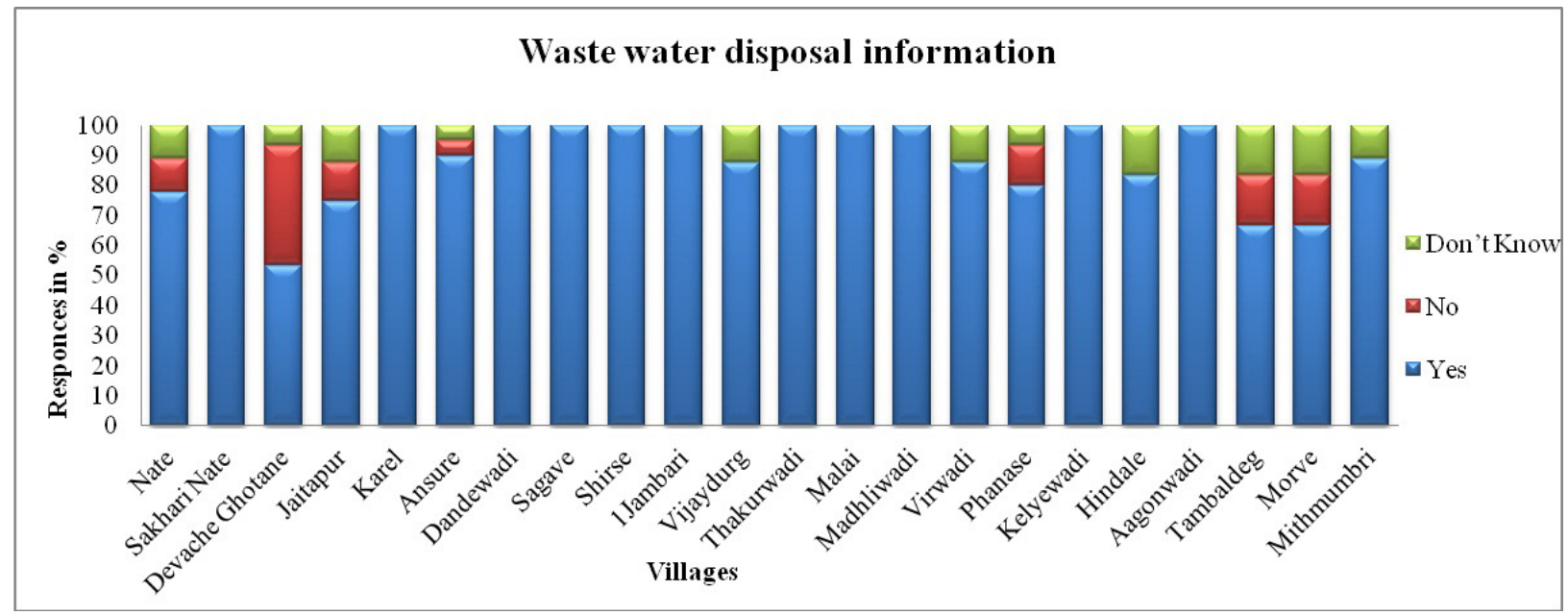

Figure 10. Knowledge about waste water disposal. 
much useful. Respondents in remaining villages are not used mangrove wood for construction purpose, there are various reason like availability of other resources i.e. other wood, lateritic blocks etc. Some respondent used mangroves for other purpose like making fish traps, fences etc.

Most of the houses are made with lateritic blocks and mud. It has noticed that the salty air which comes from sea affects on iron that used in construction and it gets weathered as compare to other material. Lateritic blocks and bricks are also used for construction. Some of the houses constructed with other wood and earth rock (Figure 6).

Mangroves grow in swamps where agricultural practice is not possible. The comments of respondents regarding agriculture practice in mangrove fields have shown in Figure 5. Near about 10\% people from Ansure and $11.1 \%$ people from Kelyewadi and mithmumbri; $16.7 \%$ from Nate and $12.5 \%$ from Shirse are practicing agricultural activities in mangrove fields. About $76.9 \%$

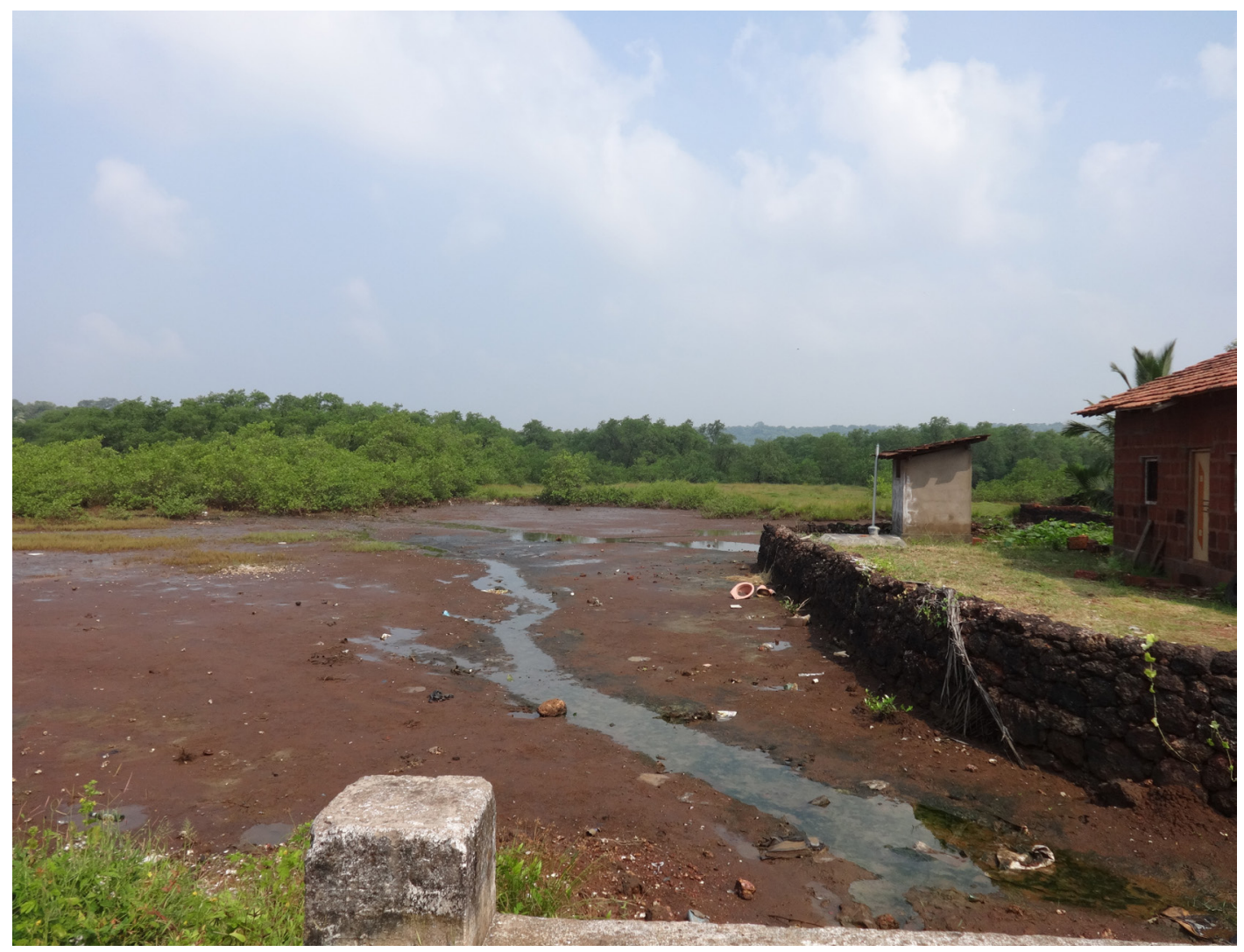

Figure 11. Waste water disposal in estuary.

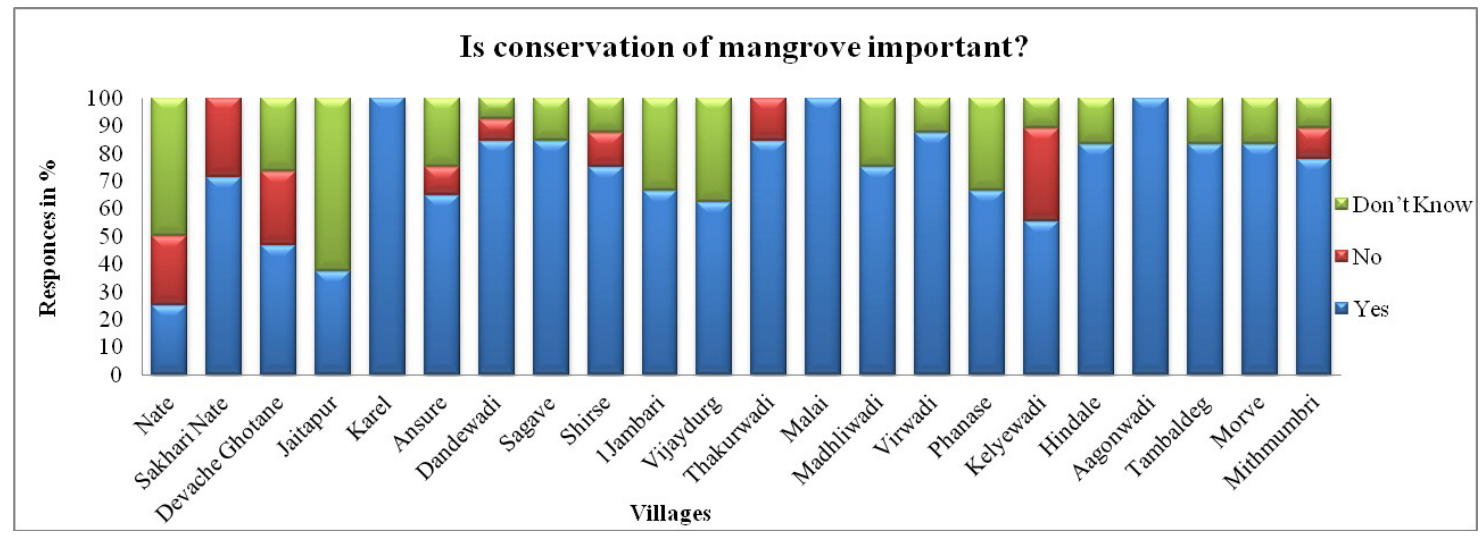

Figure 12. Is conservation of mangrove important? 
of people in Thakurwadi are practicing agriculture in mangrove area because this is their main occupation. All respondents who practice such activities in mangrove fields only cut down the mangroves in their own or private land and convert mangrove swamps into the agricultural field, cultivate rice in the same land (Figure 7). Crops are used for subsistence purpose. They grow rice, ragi, vari, pulses etc. There is no any other impact of agriculture on mangroves

Figure 8 shows the perceptions of the villagers about tourism development. In Vijaydurg 87.5\%, in Phanase 73.3\%, in Mithmumbri 77.8\%, in Tambaldeg and Morve 66.7\% and in Jambari and Aagonwadi 50\% respondents are positive towards tourism development. They think that development of tourism will improve status of village. Respondents in Vijaydurg and Devgad village are positive towards tourism. They think that Devgad and Vijaydurg are more favourable due to the large creek and there is scope for boating and water sport development. These are historical places also. There are 2-3 big hotels but compare to that tourists are less. In Thakurwadi with $76.9 \%$ of their responses, in Devache Ghotane and Kelayewadi 66.7\%, in Madhaliwadi 62.5\%, in Ansure $60 \%$ and in Jambari and Aagonwadi 50\% respondents are negative towards development of tourism in their areas, because they don't want disturbance in their daily life as well as in surrounding environment. They think that tourists make pollution. In village-Sagave (15.4\%), Shirese (12.5\%), Ansure (10\%) respondents are with neutral opinion. Some respondents are not answered.

Figure 9 reveals the opinion that people in study area are directly benefited or not from tourism. In Devache Ghotane 70\%, in Tambaldeg 66.7\%, in Vijaydurg 62.5\%, people answered as 'YES' they 'experience direct benefit from tourism. Cuisines and coasts of Konkan are attracting tourists. People in Karel, Dandewadi, Thakurwadi, Phanase, Kelyewadi, Aagonwadi and Mithmumbri (100\%) people gave negative response. In sagave 92.3\%, in Ansure 90\%, in Nate $88.9 \%$ and in Madhliwadi and Hindle $87.5 \%$ and $83.3 \%$ respectively are answered as 'NO' they not at all experience direct benefit from tourism.

Figure 10 shows the perception of the respondents about disposal of waste water information. 100\% People in Sakhari Nate, Karel Dandewadi, sagave, Shirse, Jambhari, Thakurwadi, Malai, Madhaliwadi, kelyewadi and Aagonwadi are drain their waste water into the estuary. Not only these villages but all villages which are situated along the bank of the estuaries are drain their waste water into the estuary. In Device Ghotane $40 \%$, in tambaldeg and Morve $16.7 \%$, in Phanase $13.3 \%$, in Jaitapur and Nate respectively $12.5 \%$ and $11.1 \%$ people discharge their waste water into their garden. Most of the respondent told that they are draining water in estuary after

treatment on it. Grampanchayat provide powder for mixing in this water. Some people used processed water for their plants in garden. They think that there is no effect of disposing waste water on the estuary and mangrove swamps (Figure 11).

There are problem of disasters like cyclones, flash floods and tidal waves during monsoon season. Some of the respondents are thinking that sea level is slightly increasing in their areas. It has noticed that in study area 'Mangroves' in the wetlands used for various purposes like construction, fuel, fishing etc. In view of this degradational trend, some questions have asked to respondents, i.e. "Is conservation of mangroves are important?" In Karel, Malai and Aagonwadi 100\%, in Virwadi 87.6\%, in dandewadi, Sagave, Thakurwadi $84.6 \%$, in Hindle, Tambaldeg and Morve 83.3\%, in Mithmumbri 77.8\%, in Madhaliwadi and Shirse 75\% , in Sakhari Nate 71.4\% respondent answered 'YES' conservation of mangroves is important. Perception for the answered 'No' in the villages Kelyewadi, Sakhari Nate, Devache Ghotane, Nate and Thakurwadi is $33.3 \%, 28.6 \%, 26.7 \%, 25$ and $15.4 \%$ respectively (Figure 12). Most of the respondents are unknown about the importance of mangrove conservation. According to them there is a lack of awareness regarding the conservation of mangroves. At the same time the villagers think that, mangroves are property of government and government is not allow to cut mangroves for any purpose but at the same time if mangroves are encroaching towards their owned property then they have to right to cut the mangroves (this is also a perception of some villagers). Respondents commented that, "no one has told them about the importance of mangroves. Therefore government should undertake some awareness programmes about mangrove conservation in such villages.

Figure 13 and 14 related with the status of mangroves as compare to past. Most of the people answered that the mangroves in the study area is 'Increased' because as per their perception mangroves are continuously growing for 200-300 years. They are occupying more and more area. Mangroves are having number of knee roots that's why they are continuously growing. So the local population also predicted that mangroves may increase in future. The perception of the respondents who answered 'Increased' 


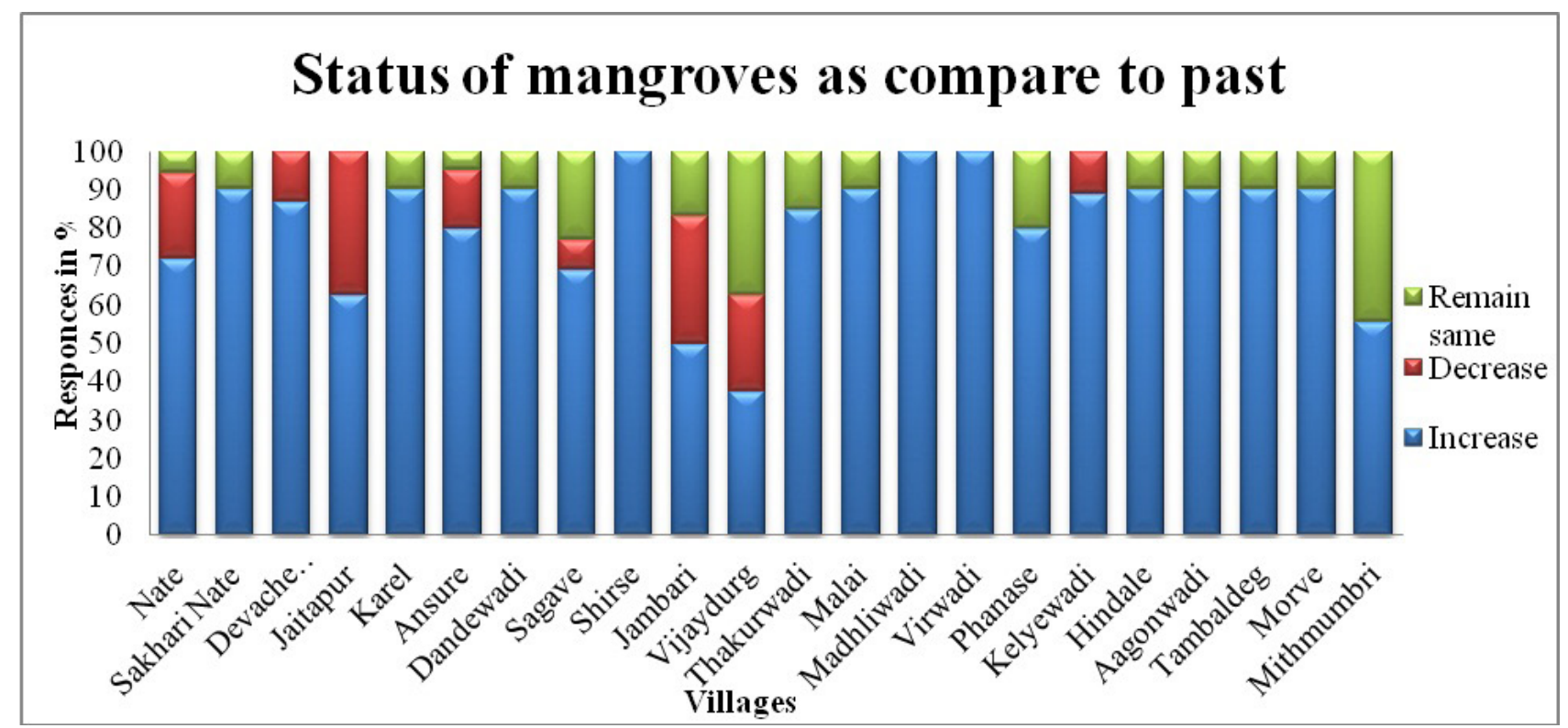

Figure 13. Status of mangrove as compare to past.

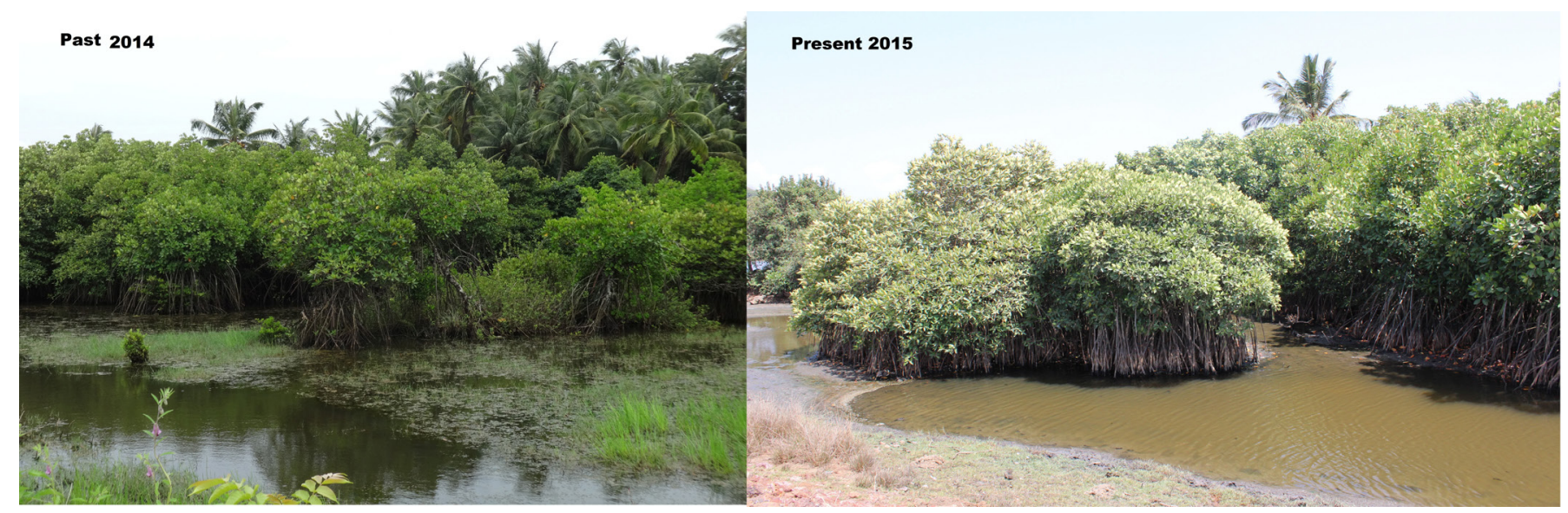

Figure 14. Past and present status of mangroves in Phanase estuary.

is in Shirse, Mdhaliwadi and Virwadi 100\%, in Sakhari Nate, Karel, Dandewadi, malai, Hindle, Aagonwadi, Tambaldeg and Morve 90\%, in Kelyewadi 88.9\%, in Devache Ghotane $86.7 \%$ and in Ansure 80\%. According to respondents in the villages of Jaitapur (37.5\%), Jambari (33.3\%), Vijaydurg (25\%), Nate (22.2\%), Ansure (15\%) and Devache Ghotane (13.3\%) mangroves are continuously decreasing due to the human intervention and some of due to natural causes. Most of the people i.e. 5-35\% are answered that the mangroves are remain same.

\section{Observations}

It has observed that, estuaries in the Rajapur and Devgad tehsils are very rich in mangrove ecosystem. Mangroves fulfill many extremely important protective, productive, and social functions. Increased population pressures in coastal areas and lack of awareness about importance of mangroves have lead to large scale conversion of mangroves to other uses. Mangroves are also used for shrimp farming and crab farming in the study area. Mangroves provide shelter and nutrients to aquatic micro organism and animals. It has physically observed that mangrove wood has used for making temporary shades in front of houses and as a fences also. It has noticed that, waste water is directly draining in the estuary without treatment, may be one of the causes for mangrove degradation. Bunds along the banks of the estuaries are protecting the inland side agricultural fields, helps to protect agriculture land from encroachment of saline water. But at the same time, 
due to these bunds the inland side mangroves are dying due to the intake of sufficient saline water. It is essential to involving local stakeholders in planning, implementation and monitoring of mangroves.

\section{Conclusion}

Overall, it is concluded that most of the respondents in the study area are not used mangrove for construction purpose but in some villages' mangrove wood used for the making of shades and as a fence. Mangroves can become an asset for tourism development because they enhance the attractiveness of estuarine environment but as per survey the respondents in the study area have diplomatic approach about tourism i.e. both positive and negative. Views of some people are favourable for tourism as it can be contribute in the socio-economic development of the ports as well as the surrounding areas. Tourist may disturb the environment through pollution hence in some villages respondents are against the tourism development. According to respondents there waste water goes in the estuaries. All villages which are situated along the estuary drain their waste water in the estuary because of poor infrastructure. Only few respondents are using this water in their garden after processing. Mangroves in the Phanase, Jaitapur and Sakhri Nate are affected by the waste water. Lastly, it has concluded that in some villages the mangrove swamps are converted into the agricultural land and also used for shrimp farming.

\section{References}

1. Sapkale JB, Rathod BL. Perception based study of coastal sand dunes in the areas of Ratnagiri Coasts, Maharashtra. Indian Journal of Science and Technology. 2016; 9(7):65761. Crossref

2. Sapkale JB. Degradation of coastal sand dunes in Mithmumbari and Kunkeshwar of Devgad Coasts Maharashtra. International Journal of Innovative Research in Science Engineering and Technology. 2014; 3(9):16097103. Crossref

3. Harty C. Mangrove in New South Wales and Victoria. Melbourne: Vista Publications; 1997. p. 47.

4. Brahmanandhan GM, Swithin B, Radjen TA, Zenith PPH, Motouri S, Akhil PS, Kumar MC, Reddy ASP. Theoretical prediction of annual energy generation from a tidal barrage with reference to tidal range at Chennai. Indian Journal of Science and Technology. 2016; 9(34):1-3. Crossref

5. Adib A. Extraction of structural curves, regression relations and structural regression relations in the tidal limit of the Karun River. Indian Journal of Science and Technology. 2010; 3(5):530-6.

6. Pandian PK, Dharanirajan K. Beach morphology and coastal protection along Ennore coast in the north of Chennai city south India. Indian Journal of Science and Technology. 2007; 1(1):1-7.

7. Traynor CH, Hill T. Mangrove Utilisation and Implications for Participatory Forest Management, South Africa. Conservation and Society. 2008; 6(2):109-16.

8. Sahu SC, Suresh HS, Murthy IK, Ravindranath NH. Mangrove Area Assessment in India Implications of Loss of Mangroves. Journal Earth Science Climatic Change. 2015; 6(5):1-7.

9. Sremongkontip S, Hussin YA, Groenindijk L. Detecting Changes In The Mangrove Forests Of Southern Thailand Using Remotely Sensed Data And Gis. International Archives of Photogrammetry and Remote Sensing. 2000; 33(B7):1-8.

10. Dahdouh-Guebas F. The Use of Remote Sensing And Gis In The Sustainable Management Of Tropical Coastal Ecosystems. Environment, Development and Sustainability. 2002; 4(2):93-112. Crossref

11. Dahdouh-Guebas F, Mathenge C, Kairo JG. Koedam N. Utilization of Mangrove Wood Products around Mida Creek (Kenya) Amongst Subsistence and Commercial Users. Economic Botany. 2000; 54(4):513-27. Crossref

12. Sampath B, Mohankumar G. Preliminary Study on the Development of Concrete with Sea Sandas Fine Aggregate. Indian Journal of Science and Technology. 2016; 9(32):1-5. Crossref

13. Zorina SO, Afanasieva NL, Khairutdinova LR, Morozov VP, Eskin AA, Marsovich GB. Paleocene-Eeocene Depositional Environments and Abiotic Events on the Southern and South-Eastern Russian Platform. Indian Journal of Science and Technology. 2016; 9(18):1-8. Crossref

14. Kazemzadeh MB, Ayyoubzadeh SA, Moridnezhad A. Remote Sensing of Temporal and Spatial Variations of Suspended Sediment Concentration in Bahmanshir Estuary Iran. Indian Journal of Science and Technology. 2013; 6(8):5036-45.

15. Zhou YW, Zhou B, Peng YS, Chen GZ. Influence of mangrove restoration on heavy metal accumulation and speciation in intertidal sediments. Marine Pollution Bulletin. 2010; 60(8):1319-24. Crossref, PMid:20378130 